\title{
Myeloid to Erythroid Ratio Measurement
}

National Cancer Institute

\section{Source}

National Cancer Institute. Myeloid to Erythroid Ratio Measurement. NCI Thesaurus.

Code C92242.

The determination of the ratio of myeloid cells compared to erythroid cells present in a sample. The measurement may be expressed as a ratio or percentage. 